\title{
Pengaruh Pengawasan Dalam Meningkatkan Efektivitas Kerja Karyawan Pada PT. Wahana Mulya Ogan Komering llir
}

\author{
Muhammad Kurniawan \\ Manajemen, Fakultas Ekonomi Universitas PGRI Palembang Palembang \\ email: iwanusman220516@gmail.com
}

\begin{abstract}
ABSTRAK
Tujuan dalam penelitian ini adalah untuk mengetahui pengaruh pengawasan dalam meningkatkan efektivitas kerja karyawan pada PT. Wahana Mulya Ogan Komering llir. Populasinya adalah karyawan tetap pada PT. Wahana Mulya Ogan Komering llirsejumlah 35 orang. Metode pengumpulan data yang digunakan adalah kuesioner dan dokumentasi. Sedangkan untuk teknik analisis menggunakan regresi linier sederhana, analisis korelasi dan uji hipotesis $t$ dengan bantuan software SPSS 17.0 for windows. Untuk hasil penelitian menunjukkan bahwa ada pengaruh yang signifikan antara pengawasan dalam meningkatkan efektivitas kerja karyawan pada PT. Wahana Mulya Ogan Komering llir. Hal ini berdasarkan hasil pengujian hipotesis yang diperoleh dimana nilai thitung lebih besar dari nilai tabel $(6,825>2,035)$ maka keputusannya adalah menolak hipotesis nol $(\mathrm{Ho})$ dan menerima hipotesis alternative $(\mathrm{Ha})$. Berdasarkan perhitungan koefisien korelasi $(\mathrm{R})$ diperoleh nilai sebesar 0,765 ,karena hasil yang didapat merupakan angka positif, hal ini berarti ada hubungan yang kuat antara pengawasan denganefektivitas kerja.Dari hasil perhitungan koefisien determinasi diperoleh nilai $r^{2}=0,585$. Hal ini berarti variabel efektivitas kerja dipengaruhi oleh variabel pengawasan sebesar $58,5 \%$, sedangkan sisanya $41,5 \%$ dipengaruhi oleh variabel lain yang tidak diteliti
\end{abstract}

Kata kunci : pengawasan, efektivitas kerja

\section{A. Latar Belakang}

Pengawasan merupakan suatu proses kegiatan yang dilakukan untuk menjamin supaya pelaksanaan kerja sesuai dengan rencana yang telah ditetapkan. Fungsi pengawasan yang merupakan bagian dari fungsi manajemen perlu diwujudkan dan dikembangkan sehingga efektivitas karyawan dapat dicapai sesuai dengan apa yang diharapkan perusahaan, dengan pengawasan efektivitas karyawan dapat ditingkatkan.

$$
\text { Tingkat efektivitas kerja }
$$
dipengaruhi oleh perkembangan, pengaturan, pemeliharaan, pemanfaatan dan pengembangan oleh manajemen, karena manajemen memiliki tanggung jawab langsung dari tenaga kerja menjadi bawahan pembinaan, sehingga sangat efektivitas manajemen bertanggung jawab untuk pekerjaan.Dalam setiap pekerjaan, karyawan membutuhkan prestasi yang efektif. Efektivitas kerja dinilai melalui proses evaluasi kinerja yang merupakan dasar bagi kenaikan gaji, bonus yang tersedia dalam organisasi, dan promosi. Maka dari itu efektivitas dalam bekerja merupakan kunci keberhasilan organisasi atau perusahaan.

Seorang pemimpin tentu akan berusaha untuk melakukan pembinaan dalam meningkatkan efektivitas karyawan berdasarkan peraturan yang ada. Peraturan yang dibuat dapat membentuk sikap karyawan dalam bekerja dan menimbulkan suasana yang tertib, sehingga pencapaian 
tujuan yang akan dicapai terlaksana dengan baik.

Dari pendapat di atas dapat disimpulkan bahwa pengawasan adalah persoalan yang sangat essensial yang tidak bisa diabaikan. Karena hakekatnya pengawasan adalah kegiatan mendeteksi apa yang dilakukan pegawai dan untuk menilai dari segi pegawai pematuhan dan pematuhan dengan dasar yang dikenakan.

Salah satu perusahaan yang menjalankan fungsi pengawasan agar dapat meningkatkan efektivitas kerja adalah PT. Wahana Mulya Ogan Komering llir. Saat ini PT. Wahana Mulya Ogan Komering Ilir dihadapkan pada tantangan yang semakin kompleks. PT. Wahana Mulya Ogan Komering llir dapat melakukan berbagai cara untuk meningkatkan efektivitas kerja karyawan. Salah satu cara yang dapat ditempuh dengan melalui pengawasan di tempat kerja yaitu membandingkan yang telah dijalankan dengan standar atau rencananya, serta melakukan perbaikan-perbaikan jika terjadi penyimpangan. Maka, dengan pengawasan dapat di ukur hasil yang telah dicapai sehingga sesuai dengan yang direncanakan. Pengawasan dilakukan pada setiap tahap agar mudah diadakan perbaikan sehingga terjadi penyimpangan-penyimpangan, sehingga resiko kelalaian, kesalahan baik yang tidak disengaja ataupun disengaja dapat terhindar.

Karyawan sebelum melaksanakan pekerjaannya terlebih dahulu diberikan pengetahuan tentang tata krama atau etika bagaimana cara melayani pelanggan sehingga kerja yang dihasilkan oleh karyawan dapat efektif, adanya kesadaran bahwa pengawasan dapat meningkatkan efektivitas kerja karyawan. Akan tetapi dalam pelaksanaannya mungkin terjadi hal sebaliknya, yaitu menurunkan efektivitas kerja karyawan.

Persaingan yang ketat menuntut perusahaan untuk bisa bertahan dan memapankan posisinya, maka perusahaan semakin menyadari perlunya menerapkan suatu manajemen yang baik dan sesuai dengan rumah tangga perusahaan agar perusahaan mampu bertahan dan terus berkembang.

\section{B. Kajian Teori}

1. Pengawasan

a) Pengertian Pengawasan

Menurut Winardi (2008:379) dalam Kadir (2009:11) pengawasan berarti mendeterminasi apa yang telah dilaksanakan, maksudnya pengevaluasi prestasi kerja dan apabila perlu menetapkan tindakantindakan korektif sehingga hasil dari pekerjaan sesuai dengan rencana.

SelanjutnyaSiagian $\quad$ (2008:139) menyebutkan bahwa pengawasan adalah bentuk pengamatan umumnya dilakukan secara menyeluruh, dengan membuat perbandingan antara dikonstatir dan yang harus dilaksanakan.

Sedangkan Handoko (2009:359), mendefinisikan bahwa Pengawasan (controlling) adalah penemuan dan penerapan cara dan peralatan merupakan jaminan agar rencana yang dilakukan sesuai yang telah ditetapkan.

Dari definisi diatas, disimpulkan bahwa pengawasan merupakan proses kegiatan agar suatu pekerjaan berjalan sesuai yang telah direncanakan.

b) Fungsi Pengawasan

Pengawasan pada dasarnya untuk mencegah terjadinya penggunaan wewenang, tenaga, uang dan perlengkapan milik suatu organisasi Handoko (2009:383). 
Adapun maksud pengawasan itu adalah untuk memperbaiki kesalahan, penyimpangan serta ketidaksesuaian tujuan dan wewenang yang ditentukan, Sule dan Saefullah (2005:14-16).

Dari batasan-batasan tersebut jelas bahwa tujuan utama dari pengawasan ialah mengusahakan agar perencanaan menjadi kenyataan. Oleh karena itu, dalam rangka sistem pengawasanyang lebih efektif, manajer segera melaporkan penyimpangan yang terjadi. Hal ini bertujuan agar pelaksanaan rencana keseluruhan benar-benar sesuai dengan yang direncanakan.

Dari pengertian pengawasan yang telah dikemukakan diatas, pengawasan dapat didefinisikan sebagai suatu alat pembimbing dan mengendali pelaksanaan rencana yang telah ditetapkan yang dapat mempermudah atau meringankan tugas-tugas para pelaksana.

Selanjutnya, Handoko (2009:362365) mengemukakan bahwa fungsi pengawasan meliputi empat unsur sebagai berukut :

1) Penetapan standar pelaksanaan.

Standar adalah alat ukur yang melakukan pekerjaan. Standarstandar ini biasanya didasarkan pada kemampuan kerja normal, Dalam hal pengawasan, sarana standar sebagai unit pengukuran yang dapat digunakan sebagai "patokan" untuk penilaian hasil. Jadi dengan standar, monitoring dapat dilakukan secara efektif dan efisien.

2) Penentuan ukuran-ukuran pelaksanaan.

Langkah penentuan ukuranukuran pelaksanaan yaitu menentukan pengukuran pelaksanaan kegiatan secara tepat. Langkah ini secara singkat ialah menentukan penunjuk hasil, maksud dari langkah ini yaitu tujuan pengawasan ini agar manajer dapat mengatasi dan memperbaiki penyimpangan yang terjadi sebelum kegiatan diselesaikan.

3) Pengukuran pelaksanaan nyata dan pembandingan dengan standar kerja.

Langkah mengukur pelaksanaan nyata merupakan proses berkelanjutan dan repetitif (berulang-ulang), dengan frekuensi aktual pada aktivitas yang sedang diukur. Sedangkan membandingkan pelaksanaan dengan standar yang telah ditetapkan adalah membandingkan hasil target yang telah diukur atau standar ditetapkan.

4) Pengambilan tindakan koreksi yang diperlukan bila pelaksanaan menyimpang dari standar.

Tindakan ini dilakukan jika kinerja rendah di bawah standar dan analisis menyatakan perlu diambil tindakan. Tindakan perbaikan dapat berupa satu atau beberapa aktivitas dalam kegiatan organisasi atau standar yang telah ditetapkan. Jadi dengan kata lain pengambilan tindakan koreksi dilakukan dengan tujuan untuk memperbaiki dan menyempurnakan segala kegiatan, kebijaksanaan serta hasil kerja yang tidak sesuai dengan rencana atau standarnya.

\section{c) Tujuan Pengawasan}

Kegiatan pengawasan dilakukan agar tujuan kegiatan berjalan atau terlaksana dengan sangat baik sehingga rencana yang diinginkan tercapai sesuai yang telah di rencanakan dan ditetapkan.

Manullang (2006:129), dalam bukunya "Dasar-dasar Manajemen" mengemukakan, "Tujuan utama dari 
pengawasan ialah mengusahakan agar apa direncanakan menjadi kenyataaan". Untuk dapat benar-benar merealisasikan tujuan utama tersebut, maka pengawasan bertujuan agar pelaksanaan pekerjaan sesuai instruksi dan agar kelemahankelemahan serta kesulitan-kesulitan yang dihadapi dalam tahap pelaksanaannya dapat terhindarkan.

Sedangkan Bohari (2005:5) mengemukakan bahwa "Tujuan utama dari pengawasan adalah untuk memahami apa yang salah demi perbaikan dimasa datang dan mengarahkan seluruh kegiatankegiatan dalam rangka pelaksanaan daripada suatu rencana sehingga dapat diharapkan suatu hasil yang maksimal."

\section{Efektivitas Kerja}

a) Pengertian Efektivitas

Konsep efektivitas bisa digunakan sebagai indikator keberhasilan suatu organisasi. Konsep ini menekankan sejauh mana tujuan dapat dicapai secara optimal. Handoko (2009:7), mengemukakan efektivitas adalah kemampuan untuk memilih tujuan yang tepat atau peralatan yang tepat untuk pencapaian tujuan yang ditetapkan.

Sedangkan menurut Winardi (2008:19) memaparkan bahwa efektivitas adalah tingkat hingga di mana suatu tindakan atau aktivitas mencapai tujuan yang ditetapkan.

Dalam memakai efektivitas setiap orang memberi arti yang berbeda, efektivitas organisasi dapat dilihat dari tiga aspek utama, yaitu ketepatan kualitas, ketepatan kuantitas dan ketepatan waktu. "efektivitas mean different to different people" menyatakan bahwa secara efektif berarti ada efek (efek, dampak, kesan), berkhasiat atau mujarab bisa membawa hasil.
Dari uraian tersebut dapat disimpulkan bahwa efektivitas merupakan kemampuan pemimpin dalam kaitannya dengan konsekuensi dari tindakan pemimpin bagi para shareholder dan para stakeholder organisasi lainnya. Namun demikiankinerja dan pertumbuhan dari sekelompok atau organisasi dari pemimpin tersebut, kepuasan pengikut dengan pemimpinnya, komitmen dari para pengikut dalam meningkatkan sasaran kelompok, kesejahteraan psikologis dan pengembangan para pengikut, mempertahankan status tinggi pemimpin, dan kemajuan pemimpin ke posisi kekuasaan yang lebih tinggi di dalam organisasi.

\section{b) Faktor-Faktor} Mempengaruhi Efektivitas Kerja Menurut Steers (2005: 209-211), ada empat (4), yaitu:

Karakteristik Organisasi

Didalamnya, terdiri dari struktur dan teknologi yang dapat digunakan. Efektivitas organisasi mempengaruhi tingkat kompleksitas dan formalitas struktur dan sistem otoritas keputusan. penggunaan teknologi terkait erat dengan struktur yang pada akhirnya mempengaruhi efektivitas organisasi.

Karakteristik Lingkungan

Keberhasilan tujuan organisasi dipengaruhi oleh kemampuan berinteraksi dengan lingkungan. Efektivitas organisasi dipengaruhi oleh dimensi lingkungan meliputi: 1) level integritas lingkungan, 2) Ketepatan persepsi lingkungan, 3 ) level rasionalitas organisasi.

$>$ Karakteristik Pekerja pengaruh manusia adalah faktor besar dalam Meningkatkan efektivitas organisasi. Perilaku manusia adalah dukungan yang sangat signifikan, tetapi juga 
dapat menjadi kendala yang bisa menggagalkan efektivitas.

$>$ Karakteristik Kebijakan dan Kegiatan Manajemen

Pencapaian tujuan dipengaruhi oleh karakteristik kebijakan dan kegiatan manajemen. Dalam hal ini termasuk kebijakan dan praktik dalam kepemimpinan tanggung jawabnya untuk meningkatkan pekerja dan organisasi mereka.

\section{c) Penilaian Efektivitas Karyawan}

Notoatmodjo

mengemukakan bahwa untuk penilaian efektivitas karyawan yaitu:

$>\quad$ Kriteria Manfaat (benefit criteria)

Untuk kriteria ini digunakan indikator produktivitas dan kualitas kerja:

1) Peninngkatan prestasi kerja

2) Penurunan absensi karyawan

3) Peningkatan partisipasi kerja

4) Peningkatan kepuasan kerja

$>\quad$ Kriteria Biaya (cost criteria)

Untuk kreteria biaya disesuaikan dengan kegiatan keamanan dan kesehatan dalam bentuk biaya pelatihan, supervisi, pembelian peralatan, penanganan, pemindahan sumber bahaya.

Dari pengertian di atas dapat dijelaskan bahwa efektivitas kerja merupakan penyelesaian pekerjaan tepat pada waktu yang telah ditetapkan, artinya apakah suatu tugas dinilai baik atau tidak sangat tergantung oleh tugas yang diselesaikannya, terutama dengan menjawab pertanyaan bagaimana cara melaksanakannya dan berapa biaya yang dikeluarkannya.

Pengawasan dalam suatu kegiatan organisasi atau kegiatan usaha memiliki hubungan yang sangat erat dengan efektifitas kerja, menurut
(Handoko, 2009:19): "Pengawasan, koordinasi dan perencanaan saling berhubungan dalam mempengaruhi efektivitas kerja". Selanjutnya (Handoko, 2009:20) menyatakan: " Pengawasan adalah penting sebagai produk perencanaan efektif. Bagi pimpinan hal ini menunjukkan apakah rencana yang telah disusun realistik atau tidak, bila rencana tidak realistik atau praktek manajemen buruk akan menyebabkan rencana tidak dikerjakan seperti yang diharapkan. Oleh karena itu, pengawasan bertindak sebagai kriteria penilaian pelaksanaan kerja terhadap rencana, pengawasan juga menjadi bagian dari rencana baru".

\section{Variabel Penelitian}

Variabeldalam penelitian ini terdiri dari variabel bebas (independen) yang disebut dengan variabel $\mathrm{X}$, merupakan variabel yang tidak tergantung dengan variabel lainnya. Variabel $\mathrm{X}$ dalam penelitian ini adalah pengawasan dan variabel terikat (Dependen) yang disebut dengan variabel $Y$, merupakan variabel yang terantung atau terpengaruh oleh variabel lainnya. Variabel $Y$ dalam penelitian ini adalah efektivitas kerja karyawan.

\section{Populasi dan Sampel}

1) Populasi

Menurut Sugiyono (2010:61), adalah wilayah generalisasi terdiri atas objek/subyek yang memiliki kualitas dan karakteristik yang ditetapkan oleh peneliti guna dipelajari kemudian diambil kesimpulannya. Populasi penelitian ini adalah karyawan tetap pada PT. Wahana Mulya Ogan Komering llir yang berjumlah 35 orang karyawan.

\section{2) Sampel}

Menurut Sugiyono, (2010: 62), Sampel adalah bagian dari jumlah dan karekteristik yang dimiliki oleh populasi 
tersebut. Penelitian ini menggunakan metode sensus, yaitu mendata keseluruhan populasi yang ada untuk dijadikan sampel. Berdasarkan sensus dilapangan, maka sampel dalam penelitian ini sebanyak 35 orang karyawan pada PT. Wahana Mulya Ogan Komering llir.

\section{E. Hasil Penelitian \\ 1. Karakteristik Responden}

Dalam penelitian ini ingin mendeskripsikan tentang pengaruh pengawasan terhadap meningkatkan efektivitas kerja karyawan. Adapun karakteristik responden diPT. Wahana Mulya Ogan Komering Ilirsebagai berikut:

a. Jenis Kelamin Responden Jenis kelamin responden dalam penelitian ini disajikan dalam tabel berikut ini :

Tabel 3

Distribusi Responden Menurut Jenis Kelamin

\begin{tabular}{|c|c|c|c|}
\hline No & Jenis Kelamin & Frekuensi(F) & Persentase (\%) \\
\hline 1 & Laki-laki & 20 & 57 \\
\hline 2 & Perempuan & 15 & 43 \\
\hline \multicolumn{2}{|c|}{ Jumlah } & $\mathbf{3 5}$ & $\mathbf{1 0 0}$ \\
\hline
\end{tabular}

Sumber : Data Primer diolah 2013

Dari hasil temuan yang ditunjukan pada tabel di atas diketahui bahwa dari 35 responden, terdapat 20 responden atau $57 \%$ adalah responden laki-laki sedangkan sisanya 15 orang atau $43 \%$ adalah responden perempuan.

b. Umur Responden

Untuk menentukan usia responden dalam penelitian ini adalah berikut ini:

Tabel 4

Responden Berdasarkan Umur

\begin{tabular}{|c|c|c|c|}
\hline No & $\begin{array}{c}\text { Rentang Usia Responden } \\
\text { (Tahun) }\end{array}$ & $\begin{array}{c}\text { Frekuensi } \\
(\mathbf{F})\end{array}$ & $\begin{array}{c}\text { Persentase } \\
(\%)\end{array}$ \\
\hline 1 & $<20$ tahun & 5 & 14 \\
\hline 2 & $21-30$ tahun & 13 & 37 \\
\hline 3 & $31-40$ tahun & 10 & 29 \\
\hline 4 & $41-50$ tahun & 3 & 9 \\
\hline 5 & $>50$ tahun & 4 & 11 \\
\hline & Jumlah & $\mathbf{3 5}$ & $\mathbf{1 0 0}$ \\
\hline
\end{tabular}

Sumber : Data Primer diolah 2013

Dari tabel di atas dapat dilihat bahwa dari 35 responden, berusia $<20$ tahun ada 5 orang atau sekitar $14 \%$ dari responden, berusia 21-30 tahun, ada 13 responden atau sekitar 37\%, untuk yang berusia 31-40 tahun mengakuisisi 10 atau sekitar $29 \%$ dari responden, sedangkan yang berusia 
41-50 tahun naik 3 responden atau sekitar 9\%, kemudian responden berusia di atas 50 tahun adalah 4 responden atau 11\%. Dari distribusi usia responden dapat dikatakan usia responden berada di usia produktif.

\section{c. Pendidikan Responden}

Tabel 5

Distribusi Responden berdasarkan Pendidikan

\begin{tabular}{|l|l|c|c|}
\hline No & Jenjang Pendidikan & Frekuensi (F) & Persentase (\%) \\
\hline 1 & SMP & 1 & 3 \\
\hline 2 & SMA & 16 & 46 \\
\hline 3 & Diploma & 10 & 29 \\
\hline 4 & Sarjana Jumlah & 8 & 23 \\
\hline \multicolumn{2}{|c|}{ Jum } & $\mathbf{3 5}$ & $\mathbf{1 0 0}$ \\
\hline
\end{tabular}

Sumber : Data diolah 2013

Dari jumlah 35responden menurut tabel diatas, sebanyak 1 orang responden atau $3 \%$ berpendidikan SMP, 16 orang atau $46 \%$ berpendidikan SMA, Diploma sebanyak 10 orangan atau $29 \%$, sedangkan sarjana sebanyak 8 orang atau 23\%. Dari atas di atas menunjukkan bahwa yang berpendidikan SMA paling dominan sebagai karyawan pada PT. Wahana Mulya Ogan Komering llir.

\section{Uji Instrumen Penelitian}

\section{a. Uji Validitas}

Untuk mengetahui data valid, reliabel dan normal maka uji validitas dan reliabilitas digunakan dengan variabel pengawasan dalam meningkatkan efektivitas kerja karyawan dilakukan perhitungan dengan menggunakan SPSS sebagai berikut:

Data yang diuji validitasnya adalah pengawasan $(\mathrm{X})$ dan efektivitas kerja (Y). Hasil uji dibandingkan dengan nilai $\mathbf{r}_{\text {tabel, }}$ dengan taraf nyata (a) $=5 \%$ dan $n=35$, yaitu 0,334 (dapat dilihat pada tabel r).Sedangkan menurut Priyatno (2010: 95), jika $r_{\text {hitung }} \geq r_{\text {tabel, }}$ Valid, kemudian jika $R_{\text {hitung }}$ $<$ Rtabel, Tidak Valid.

1) Variabel Pengawasan

Hasil Uji Validitas menggunakan korelasi product moment untuk itemitem variabel pengawasan $(X)$ terdapat pada tabel berikut ini:

Tabel 6

Hasil Uji Validitas Variabel Pengawasan (X)

\begin{tabular}{|c|c|c|c|c|}
\hline No. & $\begin{array}{c}\text { Item } \\
\text { Pertanyaan }\end{array}$ & $\mathbf{r}_{\text {hitung }}$ & $\begin{array}{c}\mathbf{r}_{\text {tabel }} \\
(\mathbf{\alpha = 5 \% )}\end{array}$ & Hasil Validitas \\
\hline 1. & Item_1 & 0,518 & 0,334 & valid \\
\hline 2. & Item_2 & 0,858 & 0,334 & valid \\
\hline 3. & Item_3 & 0,812 & 0,334 & valid \\
\hline 4. & Item_4 & 0,769 & 0,334 & valid \\
\hline 5. & Item_5 & 0,768 & 0,334 & valid \\
\hline 6. & Item_6 & 0,778 & 0,334 & valid \\
\hline 7. & Item_7 & 0,796 & 0,334 & valid \\
\hline 8. & Item_8 & 0,611 & 0,334 & valid \\
\hline
\end{tabular}


Sumber: Hasil Pengolahan Data dengan SPSS versi 17.00

Dari hasil pengolahan data dengan menggunakan SPSS versi 17.00 menunjukkan validitas hasil tes 8 item variabel pengawasan pertanyaan (X) pada taraf nyata $(\alpha)=5 \%$, semua pertanyaan valid. Sehingga bisa digunakan sebagai alat ukur dalam analisis selanjutnya.

2) Variabel Efektivitas kerja

Validitas hasil pengujian dengan menggunakan korelasi product moment untuk item dari variabel efektivitas kerja ( $\mathrm{Y}$ ) dapat dilihat pada tabel berikut :

Tabel 7

Hasil Uji Validitas Variabel Efektivitas kerja (Y)

\begin{tabular}{|c|c|c|c|c|}
\hline No. & $\begin{array}{c}\text { Item } \\
\text { Pertanyaan }\end{array}$ & $\mathbf{r}_{\text {hitung }}$ & $\begin{array}{c}\mathbf{r}_{\text {tabel }} \\
(\boldsymbol{\alpha = 5 \% )}\end{array}$ & Hasil Validitas \\
\hline 1. & Item_1 & 0,663 & 0,334 & valid \\
\hline 2. & Item_2 & 0,517 & 0,334 & valid \\
\hline 3. & Item_3 & 0,676 & 0,334 & valid \\
\hline 4. & Item_4 & 0,561 & 0,334 & valid \\
\hline 5. & Item_5 & 0,622 & 0,334 & valid \\
\hline 6. & Item_6 & 0,394 & 0,334 & valid \\
\hline 7. & Item_7 & 0,306 & 0,334 & valid \\
\hline 8. & Item_8 & 0,502 & 0,334 & valid \\
\hline
\end{tabular}

Sumber: Data diolah dengan SPSS versi 17.00

Hasil pengolahan data di SPSS versi 17 menjelaskan validitas hasil tes dari 8 item mempertanyakan efektivitas variabel $(Y)$ pada taraf nyata $(\alpha)=5 \%$, pada pertanyaan nomor 7 memiliki nilai rhitung lebih kecil dari $r_{\text {tabel }}$ sehingga dinyatakan tidak valid.Sedangkan pertanyaan yang lain memiliki nilai $r_{\text {hitung }}$ lebih besar dari $r_{\text {tabel }}$ sehingga dinyatakan valid. Berarti hanya 7 pertanyaan yang dapat dijadikan sebagai alat ukur analisis selanjutnya.

\section{b. Uji Reliabilitas}

Pengujian reliabilitas terhadap semua item pernyataan variabel pengawasan $(X)$ dan efektivitas kerja (Y), penulis menggunakan metode Cronbach Alpha.

Menurut Sekaran dalam Prayitno (2010: 98), jika nilai Cronbach's Alpha item $\geq 0,6$ maka reliabel, sedangkan jika nilai Cronbach's Alpha item < 0,6 maka tidak reliabel. Kemudian kriteria nilainya adalah sebagai berikut:

Tabel 8

Kriteria Pengujian Reliability

\begin{tabular}{|c|c|}
\hline Nilai Reliabiliti & Kriteria \\
\hline$<0,6$ & Kurang baik \\
$0,7-8,0$ & Dapat diterima \\
$>8,0$ & Baik \\
\hline
\end{tabular}

1) Variabel Pengawasan (X)

Berdasarkan hasil Uji Reliabilitas dengan menggunakan Cronbach Alpha's untuk variabel pengawasan $(\mathrm{X})$, dapat dilihat pada tabel berikut ini.

Tabel 9

Hasil Uji Reliabilitas Pengawasan (X)

\begin{tabular}{|l|l|}
\hline $\begin{array}{l}\text { Cronbach's } \\
\text { Alpha }\end{array}$ & N of Items \\
\hline 0,879 & 8 \\
\hline
\end{tabular}

Sumber: Data diolah (SPSS Versi 17)

Berdasarkan tabel di atas, untuk kontrol variabel dapat dilihat bahwa nilai Cronbach Alpha dari 0,879> 0,6 
maka dapat disimpulkan bahwa pertanyaan pada instrumen, dapat digunakan sebagai alat ukur yang handal dalam analisis selanjutnya.

2) Variabel Efektivitas kerja (Y) Berdasarkan uji reliabilitas dengan menggunakan Cronbach Alpha untuk efektivitas variabel (Y), dapat dilihat pada tabel berikut.

Tabel 10

Hasil Uji Reliabilitas Efektivitas kerja (Y)

\begin{tabular}{|l|l|}
\hline $\begin{array}{l}\text { Cronbach's } \\
\text { Alpha }\end{array}$ & N of Items \\
\hline 0,603 & 7 \\
\hline
\end{tabular}

Sumber : Data diolah (SPSS Versi 17)

Berdasarkan tabel di atas, untuk variabel efektivitas kerja dapat dilihat bahwa nilai Cronbach's Alphanya sebesar 0,603> 0,6 maka disimpulkan bahwa pertanyaan pada instrumen, bisa dijadikan alat ukur yang reliabelpada analisis selanjutnya.

Dari hasil pengolahan data primer dengan menggunakan aplikasi komputer SPSS, nilai tersebut direkapitulasi dalam tabel berikut ini:

Tabel 11

Rekapitulasi Hasil Uji Reliabilitas

\begin{tabular}{|l|l|c|c|c|}
\hline No & \multicolumn{1}{|c|}{ Variabel } & $\begin{array}{c}\text { Cronbach's } \\
\text { Alpha item }\end{array}$ & $\begin{array}{c}\text { Cronbach's } \\
\text { Alpha }\end{array}$ & Keterangan \\
\hline 1 & Pengawasan $(\mathrm{X})$ & 0,879 & 0,6 & Reliabel \\
\hline 2 & Efektivitas kerja $(\mathrm{Y})$ & 0,603 & 0,6 & Reliabel \\
\hline
\end{tabular}

Sumber :Data Diolah

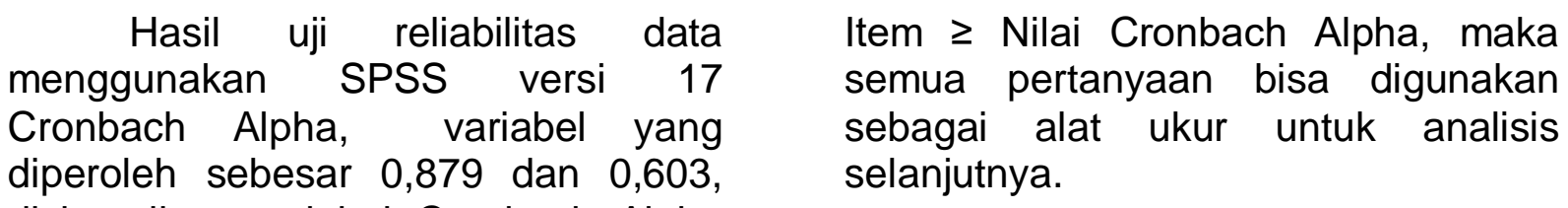
disimpulkan variabel Cronbach Alpha

\section{Analisis Regresi Linier Sederhana}

Tabel 12

Hasil Uji Regresi Liner Sederhana

\begin{tabular}{|ll|l|l|l|l|l|}
\hline \multirow{2}{*}{ Model } & \multicolumn{2}{|l|}{$\begin{array}{l}\text { Unstandardized } \\
\text { Coefficients }\end{array}$} & $\begin{array}{l}\text { Standardized } \\
\text { Coefficients }\end{array}$ & $\mathrm{t}$ & Sig. \\
\cline { 2 - 7 } & $\mathrm{B}$ & $\begin{array}{l}\text { Std. } \\
\text { Error }\end{array}$ & Beta & & \\
\hline 1 & (Constant) & 9,399 & 2,810 & & 3,345 & 0,002 \\
& Pengawasan $(\mathrm{X})$ & 0,553 & 0,081 & 0,765 & 6,825 & 0,000 \\
\hline
\end{tabular}

Sumber : Data diolah dengan SPSS Versi 17.00

Hasil uji regresi pada variabel pengawasan $(X)$ terhadap efektivitas kerja (Y) dapat digambarkan persamaan regresi sebagai berikut:

$$
\begin{aligned}
& Y^{\prime}=a+b X \\
& Y^{\prime}=9,399+0,553 X
\end{aligned}
$$

Arti persamaan ini sebagaiberikut :

- Konstanta sebesar 9,399, artinya jika pengawasan $(X)$ nilainya 0 , maka efektivitas kerja (Y) nilainya sebesar 9,399. 
- Koefisien regresi variabel pengawasan $(X)$ sebesar 0,553, artinya jika pengawasan mengalami kenaikan 1\%, maka efektivitas kerja (Y) akan mengalami peningkatan sebesar
0,553 . Koefisien bernilai positif antara pengawasan dengan efektivitas kerja, artinya semakin tinggi pengawasan maka akan semakin meningkatkan efektivitas kerja.

\section{Analisis Korelasi}

Tabel 13

Model Summary

\begin{tabular}{|l|l|l|l|l|}
\hline Model & R & R Square & $\begin{array}{l}\text { Adjusted } \\
\text { R Square }\end{array}$ & $\begin{array}{l}\text { Std. Error of } \\
\text { the Estimate }\end{array}$ \\
\hline 1 & $0,765(\mathrm{a})$ & 0,585 & 0,573 & 1,596 \\
\hline
\end{tabular}

Dari tabel di atas, dapat di lihat bahwa nilai korelasi (R) antara pengawasan $(X)$ terhadap efektivitas kerja $(Y)$ adalah sebesar $r=0,765$ yang berarti bahwa hubungan antara pengawasan $(X)$ terhadap efektivitas kerja $(Y)$ adalah kuat. Sementara itu kriteria nilainya adalah sebagai berikut:

Tabel 14

Interval Koefisien Korelasi

\begin{tabular}{|c|c|}
\hline $\begin{array}{c}\text { Interval } \\
\text { Koefisien }\end{array}$ & $\begin{array}{c}\text { Tingkat } \\
\text { Hubungan }\end{array}$ \\
\hline $0,00-0,199$ & Sangat Rendah \\
$0,20-0,399$ & Rendah \\
$0,40-0,599$ & Sedang \\
$\mathbf{0 , 6 0 - 0 , 7 9 9}$ & Kuat \\
$0,80-1,000$ & Sangat Kuat \\
\hline
\end{tabular}

Nilai korelasi $(\mathrm{R})$ yaitu sebesar 0,765 berarti berada pada range 0,60 0,799 . Hal tersebut berarti bahwa korelasi antara pengawasan (X) terhadap efektivitas kerja $(\mathrm{Y})$ adalah kuat dan positif. Maksudnya jika dengan adanya peningkatan terhadap pengawasanvaariabel $(X)$, maka akan diikuti peningkatan efektivitas kerja $(\mathrm{Y})$ dengan berarti. Sebaliknya, jika ada penurunan pengawasan (X), maka akan diikuti oleh penurunan efektivitas kerja $(\mathrm{Y})$ dengan ikatan yang kuat.

\section{Analisis Determinasi $\left(\mathbf{R}^{2}\right)$}

Analisis determinasi dalam regresi linier sederhana digunakan untuk menentukan persentase kontribusi dari pengaruh variabel independen terhadap variabel dependen. Koefisien menunjukkan ini berapa besar persentase variasi variabel independen yang digunakan dalam model mampu menjelaskan variasi dari variabel dependen.

Berdasarkan tabel di atas angka yang diperoleh $R 2$ ( $R$ square) dari 0,585 menjelaskan bahwa variabel pemantauan menjelaskan perubahan pada variabel efektivitas dari $58,5 \%$, sedangkan sisanya adalah variabel lain.

\section{Pengujian Hopotesis}

Setelah diperoleh hasil perhitungan regresi linier sederhana dan koefisien korelasi antarapengawasan dan efektivitas kerja, maka dilakukan uji hipotesis dengan langkah-langkah sebagai berikut :

\section{a. Menyusun formulasi $\mathrm{Ho}$ dan $\mathrm{Ha}$}

Berdasarkan hipotesis yang sudah dikemukakan sebelumnya, bahwa terdapat pengaruh yang signifikan pada pengawasan dalam meningkatkan efektivitas kerja karyawan PT. Wahana Mulya Ogan Komering Ilir. Dari hipotesis tersebut 
akan diformulasikan hipotesis (Ho) dan hipotesis alternative (Ha) sebagai berikut :

Ho : Tidak terdapat pengaruh yang signifikan pengawasan dalam meningkatkan efektivitas kerja karyawan PT. Wahana Mulya Ogan Komering llir.

$\mathrm{Ha}$ : Memiliki pengaruh yang signifikan pengawasan dalam meningkatkan efektivitas kerja karyawan PT. Wahana Mulya Ogan Komering llir.

\section{b. Kriteria Pengujian :}

- Apabila $t_{\text {hitung }}<t_{\text {tabel }}$, maka $\mathrm{Ha}$ ditolak dan Ho diterima.

Artinya tidak terdapat pengaruh yang signifikan antara pengawasan dalam meningkatkan efektivitas kerja karyawan PT. Wahana Mulya Ogan Komering llir.

- Apabila thitung $>t_{\text {tabel, }}$ maka $\mathrm{Ha}$ diterima dan Ho ditolak.
Artinya terdapat pengaruh signifikan padapengawasan dalam meningkatkan efektivitas kerja karyawan PT. Wahana Mulya Ogan Komering Ilir

Nilai $t_{\text {tabe }}$ pada taraf nyata $(\alpha)=$ $5 \%: 2=2,5 \%, d k=n-2=35-2=$ 33, adalah sebesar 2,035 (lihat pada lampiran $\left.t_{\text {tabel }}\right)$.Menurut Prayitno (2010:59), jika thitung $\geq$ ttabel, maka Ho ditolak dan $\mathrm{Ha}$ diterima, sedangkan jika $t_{\text {hitung }}<$ ttabel, $_{\text {, maka Ho diterima dan }}$ Ha ditolak.

Dapat dilihat bahwa nilai

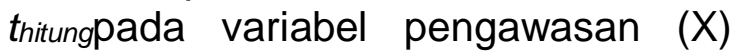
adalah sebesar 6,825 , hal ini berarti thitung $(6,825) \geq t_{\text {tabel }}(2,035)$, oleh karena itu Ho ditolak dan $\mathrm{Ha}$ diterima, makaterdapat pengaruh yang signifikan antara pengawasan dalam meningkatkan efektivitas kerja karyawan PT. Wahana Mulya Ogan Komering llir.

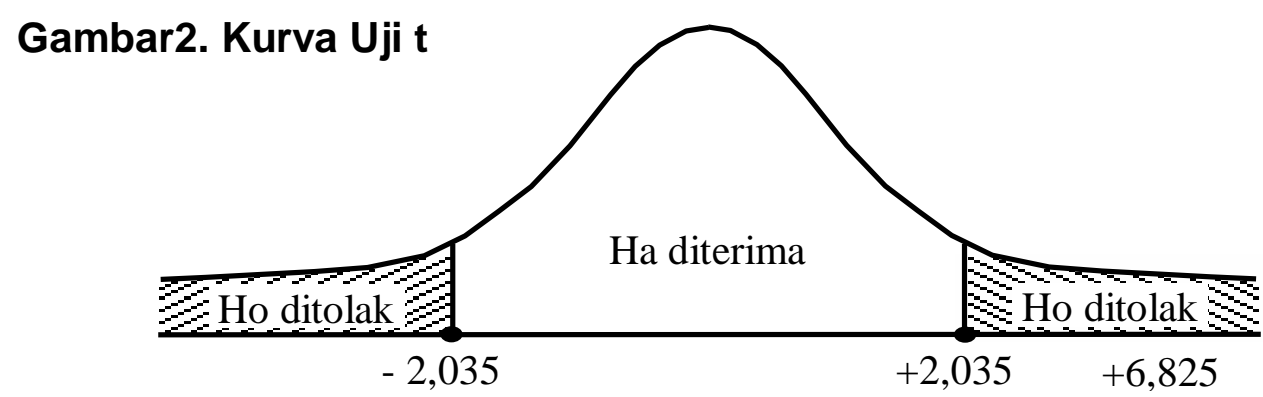

Gambar di atas menunjukan bahwa area $\mathrm{Ha}$ diterima dan $\mathrm{Ho}$ ditolak. Bagian yang di arsir adalah area yang ditolak dan bagian area yang tidak diarsir Ha diterima. Melalui pengujian di atas, maka diketahui thitung lebih besar dari tabel $(6,825 \geq 2,035)$, sehingga dapat disimpulkan bahwa pengawasan berpengaruh dalam meningkatkan efektivitas kerja karyawan pada PT. Wahana Mulya Ogan Komering llir.

\section{F. Pembahasan}

Dengan diketahuinya hasil analisis, bahwa pengawasan berpengaruh kuat dalam meningkatkan efektivitas kerja karyawan pada PT. Wahana Mulya Ogan Komering llir.Dengan hasil hitung persamaan regresi diperoleh yaitu $Y^{\prime}=9,399+$ $\mathbf{0 , 5 5 3 X}$ dimana nilai $a=9,399$ dan nilai $b=0,553$.

Ini berarti bahwa efek dari pengawasan dalam meningkatkan efektivitas karyawan di PT. Mulya naik Ogan Ogan llir terdeteksi oleh $X$ dan diikuti oleh peningkatan nilai $Y$ berarti 
bahwa jika pengawasan meningkat maka efektivitas kerja juga akan meningkat.

Dengan menghitung koefisien korelasi $(R)$ nilai yang diperoleh oleh 0,879maka jika hasilnya angka positif, artinya ada korelasi yang kuat untuk efektivitas dan pengawasan.

Kemudian untuk mengetahui hasil perhitungan koefisien korelasi, dapat digeneralisasi atau tidak, itu akan memerlukan perbandingan dengan rtabel. jika tingkat kesalahan diatur ke $5 \%$ dengan $n=35$ maka diperoleh rtabel 0,334 untuk rhitung nilai yang lebih besar dari nilai rtabel baik untuk kesalahan 5\% (0,879> 0,334) sehingga $\mathrm{Ho}$ ditolak dan $\mathrm{Ha}$ diterima. Kesimpulannya ada hubungan yang positif dan signifikan dari 0,779 antara variabel kontrol dengan efektivitas karyawan. Oleh karena itu, data dan koefisien sampel dapat digeneralisasi untuk populasi.

Dari hasil perhitungan koefisien korelasi analisis koefisien determinasi $R=0,765 r 2=0,7652=0,585$. Sarana variabel efektivitas dipengaruhi oleh kontrol variabel $58,5 \%$, sisanya $41,5 \%$ dipengaruhi oleh variabel lain yang tidak diteliti.

Berdasarkan uji hipotesis diperoleh nilai $t=6,825$ lebih besar dari tabel $=2,035$ pada tingkat 0,05 , untuk df $=\mathrm{n}-2=35-2=33$. Jadi nilai $\mathrm{t}$ lebih besar dari nilai t tabel $(6,825>$ 2,035) maka keputusan tersebut menolak hipotesis nol (Ho) dan hipotesis alternatif diterima $(\mathrm{Ha})$ yang berarti tidak ada pengaruh pengawasan dalam meningkatkan efektivitas karyawan di PT. Mulya naik Ogan Ogan llir. Yang diperoleh dapat disimpulkan hubungan secara statistik positif kedua variabel, yang berarti pengawasan memiliki pengaruh yang kuat serta signifikan pada efektivitas kerja.

\section{G. Kesimpulan dan Saran \\ 1) Kesimpulan}

Berdasarkan analisis data yang telah dilakukan dan pembahasan yang diperoleh, maka dapat disimpulkan:

a. Ada pengaruh antara pengawasan dalam meningkatkan efektivitas kerja karyawan pada PT. Wahana Mulya Ogan Komering Ilir..Hal ini berdasarkan hasil pengujian hipotesis yang diperoleh dimana nilai thitung lebih besar dari nilai $t_{\text {tabel }} \quad(6,825>2,035) \quad$ maka keputusannya adalah menolak hipotesis nol $(\mathrm{Ho})$ dan menerima hipotesis alternative $(\mathrm{Ha})$.

b. Berdasarkan hasil perhitungan koefisien korelasi ( $R$ ) diperoleh nilai 0,765 sehingga hasilnya angka positif, berarti ada korelasi yang kuat antara efektivitas pengawasan.

c. Hasil perhitungan diperoleh nilai koefisien determinasi r2 $=0,585$. Kemudian efektivitas variabel dipengaruhi oleh kontrol variabel $58,5 \%$, sisanya $\quad 41,5 \%$ dipengaruhi oleh variabel lain.

\section{2) Saran}

Hasil analisa dan pembahasan, beberapa saran yang disampaikan dalam penelitian ini adalah :

a. Pimpinan harus memperhatikan bawahannya dengan baik untuk mendukung pekerjaan yang dilaksanakan oleh pegawai, sehingga dapat mendorong efektivitas kerja.

b. Pengawasan perlu ditingkatkan secara berkesinambungan dengan terus memperketat aturan-aturan terhadap pegawai, sehingga diharapkan dengan pengawasan yang tinggi dapat meningkatkan efektivitas kerja secara keseluruhan. 
c. Efektivitas kerjaberkaitan erat dengan pengawasan untuk mencapai tujuan organisasi yang efektif dan efisien. Untuk itu diharapkan perusahaan harus terus memperhatikan pengawasan untuk meningkatkan efektivitas kerja.

\section{DAFTAR PUSTAKA}

Bohari, H. 2005. Pengawasan Keuangan Negara. Jakarta: Rajawali pers

Handoko, T. Hani. 2009. Manajemen Sumber Daya Manusia. Yogjakarta: BPFE.

Kadir. 2009. Perbedaan Motivasi Karyawan Honor dan PNS. [Online]. Tersedia: http://trainermuslim.com/perbeda an-motivasi-karyawan-honor-danpns.html. [5April 2013]
Manulang M.. 2006. Dasar-Dasar Manajemen. Bandung: Ghalia Indonesia.

Notoatmodjo, Soekidjo. 2009. Pengembangan Sumber Daya Manusia. Penerbit Rineka Cipta. Jakarta.

Steers, Richard M. 2005. Efektivitas Organisasi. Jakarta:Erlangga

Sugiyono. 2009. Metode penelitian Bisnis. Bandung : Alfabeta

Sugiyono. 2010. Statistika untuk Penelitian. Cetakan ke-16, CV. Alfabeta, Bandung.

Trisnawati Sule, Ernie \& Kurniawan, Saefullah. 2005. Pengantar Manajemen. Jakarta: Prenada Media.

Winardi. $2008 . \quad$ Manajemen Perkantoran dan Pengawasan, Bandung, CV. Mandar Maju. 